WIAS Discussion Paper No.2020-002

The Royal Consultants: The Intendants of France and the Bureaucratic Transition in Pre-modern Europe

June 5, 2020

Yu Sasaki

Faculty of Law and School of International Studies, Kanazawa University

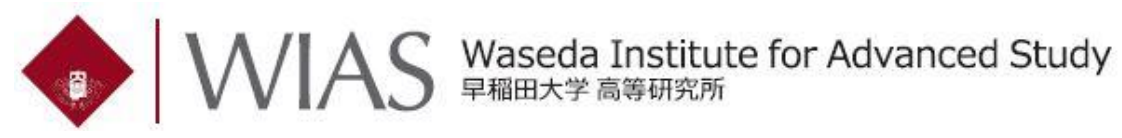

1-21-1 Nishiwaseda, Shinjuku-ku, Tokyo 169-0051, Japan

Tel: 03-5286-2460 ; Fax: 03-5286-2470 


\title{
The Royal Consultants: The Intendants of France and the Bureaucratic Transition in Pre-modern Europe
}

\author{
Yu Sasaki ${ }^{\dagger}$ \\ This version: May 13, 2020 \\ Comments welcome
}

\begin{abstract}
This article explores the pre-modern French bureaucrats of the intendants as proto-modern bureaucrats. Historical research highlights their role in consolidating the state's authority, but few works provide empirical evidence on the intendants as bureaucrats. My paper fills this gap by constructing a new data set of 430 intendants for the period of their most systematic use from 1640 to 1789 . My panel data set comprises the prosopography of nearly universal observations in the period to document evidence on recruitment, promotion, and family backgrounds. My findings indicate that although France relied on the intendants for governance, it did not manage them well as the distribution of service duration and appointment age varies greatly. Dense networks intendants form through kinship and marriage also threaten impersonality. My analysis suggests the difficulty of structuring incentives to follow and implement rules.
\end{abstract}

${ }^{\star}$ I thank seminar participants at Keio University and Kwansei Gakuin University and participants at the 2020 Winter Workshop of the Japan Society for Quantitative Social Science for their constructive feedback to the previous drafts. I also thank Beechan Ohn for his research assistance. Financial support from the Japan Society for the Promotion of Science (18H05666) is gratefully acknowledged. All errors are mine.

${ }^{\dagger}$ Assistant Professor, Faculty of Law and School of International Studies, Kanazawa University. E-mail: ysasaki@staff. kanazawa-u.ac. jp. See yusasaki. squarespace. com for the most updated version. 


\section{Introduction}

In the study of political development, hypotheses based on macrohistorical forces have been predominant. One of the most influential is the bellicist hypothesis, in which interstate war poses an existential threat to states and urges rulers to centralize authority by investing in the military, administration, and finance. The convention focuses on how rulers ensure revenue to survive (Downing 1992; Ertman 1997; Tilly 1992), while others see rulers as seeking glory more (Hoffman 2015). Another strand explores the dynamics between state and society, where societal actors function as a constraint on the way rulers govern. In this approach, how constituting actors are organized before modern times explains state capacity (Gorski 2003; Migdal 1988; Spruyt 1994), constitutional structure (Ziblatt 2006), and representative institutions (Putnam 1993).

A growing body of recent scholarship highlights the role of individual rulers. It is founded on a political-economy tradition whose key assumption is that rulers maximize revenue or ensure survival under constraints (Besley and Persson 2009, 2010; Levi 1988; Olson 1993). Recent research examines how competition for power among elites shapes the extent to which state capacity develops. The competition can start in many ways, including major economic shocks (Beramendi, Dincecco, and Rogers 2019; Garfias 2018), the geographical distribution of elite kin networks (Wang 2019), and the mode of production (Mares and Queralt 2015; Vogler 2018). State capacity depends on not only the interactions among political elites but also who wins.

The transition from patrimonialism to bureaucracy has not been widely investigated. Extant scholarship suggests that it happens when there is a strong demand for an effective bureaucracy. This is a key assumption in the bellicist approach to explaining authority centralization to facilitate war finance. Strayer $(1970,70-1)$ points to the variation in the type and the rate of taxes and the chronic under-collection of revenue that went to the royal treasury in the mid-fourteenth century as incentives for a more efficient way to generate revenue. More generally, Weber $(1978,968)$ offers a broad framework in which general hypothesis that the shift would take place only after a stable inflow of revenue is well-established so that the state could hire a number of officials who are trained as bureaucrats and specialize in narrow fields. Weber suggests that one could identify 
the transition from patrimonialism to bureaucracy by examining the management and exercise of authority. On management, patrimonial rule is personalistic while bureaucracy is structured: The former focuses on individuals who tend to recruit subordinates from their own family members and relatives to ensure obedience (Weber 1978, 1026). This method hardly separates the public sphere in government affairs from the private one in family affairs. Since patrimonialism is a private form of governance, the right to hold an authority-bearing office (legitimacy) and the scope of such authority (jurisdiction) depend principally on individuals' attributes as opposed to positions they hold (Weber 1978, 1029). Bureaucracy, by contrast, bears structure, where it is institutions-i.e., rules and regulations - that define the legitimacy and jurisdiction of authority (Weber 1978, 956). When it comes to access, bureaucratic positions in general can only be acquired through objective criteria such as examination and observable performance, while patrimonial offices may be venal in which officeholders often take advantage of them as a personal property to expand wealth and inherit them to their offspring upon their death (Weber 1978, 968). Similarly, patrimonialism is distinct from bureaucracy in the exercise of authority. Patrimonial rulers typically resort to personal discretion upon meting out authority or deciding on the limitations of their authority (Weber 1978, 1029). There is an inherent uncertainty about whether (or the degree to which) the ruler exercises his power to maintain order or observes those limits. Bureaucracy relies on more formal measures. Officials follow written rules to guide their decision on when and how to distribute justice. These are generalizable by being transmitted from one bureaucrat in a given position to the next (Weber 1978, 958).

In this paper, I study a case of a first bureaucratization effort in pre-modern Europe by drawing on France. Existing research agrees that the bureaucracy of the Weberian ideal type has emerged only in modern times, but European states did make an attempt to establish proto-modern bureaucratic functions. France constitutes an intriguing case in understanding the evolution of bureaucracy in European history. The literature on state-building puts it in what some may consider the "middle" category among European powers: France lags behind early starters such as England and the Netherlands while its state capacity is stronger than its eastern neighbors such as Hungary and 
Poland (Ertman 1997; Gorski 2003). Throughout the pre-modern period, France introduced a series of "reforms" to centralize rule and consolidate authority but never did away altogether with proprietary officeholding and other patrimonial practices, in particular tax farming (Johnson and Koyama 2014). I focus on the development of the French institution called intendancy. Historians argue that it is one of the first, if not the first, bureaucracies developed in pre-modern Europe that exhibit attributes of the Weberian ideal type (Kettering 1986). It is a unit within the French royal administration responsible for facilitating the assessment and collection of taxes, undertaking judicial investigations, and handling administrative functions. Intendancy has some general criteria on recruitment and promotion for the intendants, those who serve in it. In the historical literature, the intendants play a crucial role, by being dispatched as the king's representatives throughout the royal domain, in not just enforcing rules but also consolidating authority when Paris was unable to project power effectively in the countryside.

In this paper I first outline a framework in which the French state came to rely on these officials in provincial governance. I highlight how the mounting financial indebtedness made the government's need to raise revenue more efficiently acute. My analysis covers the role of the intendants from 1640 through 1789, the last year of the ancien régime. Although the intendants had been used at least by the mid-sixteenth century, they came to play a greater role in French political development by bridging between Paris, which wants centralization, and provincial authorities, some of which resist it. I focus on recruitment and promotion in the bureaucratization of intendancy as these are foundational. I discuss how officials have an incentive to complete the assigned tasks and demonstrate competency when they are dispatched to a locale far from Paris and no senior officials could monitor them. I also discuss limitations of intendants as modern bureaucrats by pointing out that the institution was not designed to modernize the entire state apparatus. Family wealth continued to matter in this period and prospective intendants who are financial disadvantaged needed to compete in an unequal playing field.

The bulk of my paper describes a new data set and presents quantitative evidence. It is a panel data set consisting of 430 intendants from 1640 to 1789 . It includes all observations who have the 
record of at least one intendant appointment in the 150-year period and collects information on their prosopographical attributes such as date of birth, date of death, place and duration of appointment, and family relations. Evidence shows that intendants were used systematically throughout the period and dispatched to not only most provinces in continental France but also France's overseas territories. In addition, my data indicates a great variability in the distribution of appointment age and service duration, suggesting that the rules about assignment, if they existed, were applied quite liberally. I also document evidence on familial ties among these intendants. It details not only how a number of intendants come from the same families across generations but also how these families expand their networks through marriage. For instance, two families can form a legal relationship by allowing a female member of one intendant's family to marry another intendant from a different family. I offer evidence on the geographical distribution of these connections. My findings on family and marriage ties suggest that continued venality made it difficult for the royal administration to run intendancy as a bureaucracy by Weber's standard.

I make two contributions in this paper. My main contribution is to document quantitative evidence on a number of dimensions of intendancy as a bureaucracy. Although the literature on France's political history highlights the role of the intendants in its political development, its evidence has centered on a series of illustrations of individual intendants in specific instances. My paper is the first to present a panel data set on nearly the universe of observations in the period when intendants are systematically used. My data set allows me to provide as complete information as possible about who these intendants are and when, where, and how they work. In particular, it describes biographical details including date of birth and date of death so that I can put the bureaucracy in a larger historical context. My paper is also the first to offer family- and marriage-related information. The specialized literature on the intendants has made virtually no discussion about it. My second contribution is that my findings can put the study of intendants in the broader literature on political development. In the historical scholarship, Richard Bonney, a preeminent historian of early-modern France, produces exemplary research on the role of intendants in French political and financial history (Bonney 1978). There are also studies that offer prosopographical information 
about intendants (Gruder 1968), although their breadth is limited to certain time periods. The literature has been successful at establishing the notion in social sciences that intendants function as proto-modern bureaucrats, because "they lacked ties to either local elites or the hierarchy of venal officeholders responsible for administration of the fiscal system" (Fukuyama 2011, 343). My paper builds on the previous research and takes advantage of published and digital sources to construct a larger data set.

\section{Analytical Framework}

States in early-modern Europe were, in general, slow to establish bureaucracy or a hierarchical organization to rule their domain. For the polities were "composite"-states comprised of a mixture of subunits knit together by marriages, treaties, and alliances (Elliott 1992; Koenigsberger 1987; Nexon 2009). In an environment where the central government remained unable to impose authority throughout territory, the ruler faced "fiscal fragmentation," in which he had to negotiate with local powerholders individually to determine the tax rates (Dincecco 2009, 2015). The fragmentation yielded under-taxation for the state, because each local strongman responsible for assessing and collecting the taxes has the incentive to free-ride on the contribution of others (Dincecco 2009, 51). As scholars points out, France was the first among European countries to invest in centralized institutions (Fukuyama 2011, 336; Strayer 1970, 49). My historical illustrations thus draw primarily from the French experience as an early state-builder. England, by contrast, fits less neatly: while it developed its state at a faster rate than France, its relatively smooth path was thanks to "less composite" conditions, i.e., smaller territory, fewer and weaker domestic rivals, and greater homogeneity in population (Strayer 1970, 36-7; Johnson and Koyama 2017, 5). In France, Philip II (r. 1180-1223) started to strengthen state institutions toward the end of the twelfth century, when the government sent royal agents to fill key positions of provincial offices in exchange for local autonomy (Strayer 1970, 50-1). This policy was designed to assert state authority over local strongmen, but governance required cooperation from them. In the fourteenth century, France built new state- 
level departments on taxation and justice, but the operation remained local: it continued to rely heavily on tax-farmers to raise revenue generally and on merchants to collect salt taxes (the gabelle) (Strayer 1970, 73-4). As a result, greater local knowledge was required for tax farmers than England by the turn of the sixteenth century, leaving the centralization of authority challenging (Johnson and Koyama 2014, 10).

Despite an early start, the pre-modern French state remained primarily patrimonial. One major reason is its inability to consolidate authority in a large territory, because it had limited technologies of control in terms of communications, transportation, and record-keeping. ${ }^{1}$ For instance, France was one of the first to invest in state-owned postal service in the mid-fifteenth century following the earlier experiment in Germany. The investment made the service fast and reliable by early-modern standards, but France continued to have difficulty imposing authority throughout the land (Allen 1972; Sasaki 2020; Vittu 2001). A weak infrastructure meant that pre-modern France chronically faced fiscal shortages. Although direct taxes (those on land and production) are more predictable than indirect taxes (those on sales and customs), in France the former came in at too slow a pace to the state (Collins 2009, 60). The venality of royal offices was deemed more convenient, because this method raised cash more quickly through bidding than the regular cycle of taxation. One example is the office of the royal provosts (prévôts royaux) created by the late eleventh century, in which the purchasers are tasked to raise revenue and undertake judicial functions. They have an incentive to pay for this "right to collect taxes" as it is hereditary and they see it as a long-term asset to generate income not just for them but also their descendants (Spruyt 1994, 100). Yet venality alone was scarcely sufficient to fill the state coffers: the French state was chronically indebted throughout the early-modern period. The repeated bankruptcies of 1557-58, 1602, 1634, 1648, 1721, and 1789 gave monarchy the visceral sense of the dire and chronic fiscal conditions (Collins 2009, 60). These fiscal imbalances constitute major impediments to the modernizing of the French state. ${ }^{2}$

One change that could mark a transition from patrimonialism to bureaucracy is the reinvigo-

\footnotetext{
${ }^{1}$ Kiser (1994) argues based on a principal-agent theory that these conditions also tend to make the state rely on tax farming. See also Scott (1998) on states' strong inclination to control so that populations become "legible."

${ }^{2}$ See, for instance, Bonney (1981) and Collins (1988) for the fiscal dimension of early-modern France.
} 
ration of the institution of intendancy. The officials who serve in it, the intendants, are expected to carry out investigations on a royal assignment in a given locality. It is crucial to stress the fact that intendancy is not newly designed to address the existing fiscal and administrative problems. France had been using it, albeit sporadically, since at least 1551 under the reign of Henry II (r. 1547-59) (Collins 2009, 63). It is Cardinal Richelieu in 1634 who made it a more permanent organization by sending these officials as the king's deputies to much of the généralités, the administrative unit roughly equivalent of the province. In the following decade, intendants were dispatched to all généralités and even overseas territories including today's Canada, Haiti, Mauritius, and the French Caribbean. The convention in historical research is that intendancy strengthened the authority of the French state by promoting greater degrees of impersonal recruitment and merit-based promotion. These are compatible with some of the defining characteristics of modern bureaucracy in Weber (1978). He argues that bureaucratic office-holding is a "vocation," in which staff need to be qualified to undertake assigned duties, in contrast to venal office-holding, where wealthy individuals acquire a position to assist their income in exchange for some services (Weber 1978, 958-59). As for promotion, modern bureaucracy provides officials with a career, which they expect has some known structure in terms of seniority and merit (Weber 1978, 963). I will discuss these dimensions of intendancy as an incipient bureaucracy in the rest of the section.

As a bureaucracy, intendancy expanded significantly under Richelieu in three areas. The first is the geographical scope. In the decade of 1617-27, during which Richelieu entered the king's council and became chief minister, intendants were present only in twelve provinces. It is Lyonnais and Languedoc, two main provinces of the pays d'états or recently acquired domains, that saw continuous appointments in this period. These provinces include Lyon, an economic hub, and politically important towns such as Toulouse, where the Protestant Huguenots had a sizable presence (Bonney 1978, 33). The second is the volume of appointments. Prior to the expansion, the French state used the institution only sparingly. Between 1560 and 1630, roughly 120 appointments were made (Bonney 1978, 33). Assuming that one intendant is assigned for each of the twenty-two généralités every year on the rotation of one year, there can be the maximum of 22 généralités $\times 70$ years $=$ 
1,540 intendant-years. 120 appointments mean 7.8 percent. This back-of-the-envelope calculation suggests that the state had not relied upon intendancy as a useful tool of authority consolidation. The third is the scope of responsibilities. When intendants were rolled out on a regular basis in the 1640s, their formal title bears the intendants de la justice, police et finances. It refers to three main areas of responsibility: judicial investigations (justice), administrative functions (police), and financial matters (finances). Previously, the scope had been narrower. By the early seventeenth century, the primary task was justice-related. Intendants were assigned on a mission to collect or suppress local grievances and report back to the state (Bonney 1978, 41). Then financial duties were added to the portfolio. Intendants went to pays d'élections to conduct investigations on the assessment and collection of the taille, a direct tax and a primary source of state revenue (Bonney 1978, 33). Finally, as Richelieu used intendants more frequently, their role grew to undertake police functions. ${ }^{3}$ In the late 1630s, one intendant was on an order to levy a forced loan on major cities such as Paris and Rouen. This assignment served a key precedent upon which subsequent commissions were modeled (Bonney 1978, 43-4). The ruling on August 22, 1653 put it in writing, stating that intendants would carry out the task of assessing taxes on a regular basis. Their administrative duties cover not just pays d'élections but also pays d'états which enjoyed a degree of autonomy over taxation through provincial assemblies (Bonney 1978, 49). This is historically significant, because the state would no longer follow the distinction between the two administrative districts and aim for greater uniformity in governance.

Who are the intendants? They are high-ranking government officials who serve as agents on the king's behalf in the designated généralité. The formal title, intendants de la justice, police et finances, is distinct from the intendants des finances (intendants of finance), who assist the chief financial advisor for the king (contrôleur général des finances or controller general) and report to the royal council of finances headed by the controller general; they focus more narrowly on financial matters and are venal officeholders. ${ }^{4}$ The institutional innovation here is that the position of an intendant

\footnotetext{
${ }^{3}$ Bonney $(1978,40)$ points out that the fact that a few senior members of the king's council who were former intendants and were effective in their positions demonstrated the utility of intendancy among council members.

${ }^{4}$ According to Collins $(2009,130)$, it is Jean-Baptiste Colbert in 1665 who became controller general under Louis
} 
is a royally-commissioned one. Unlike other government positions, it is not a purchasable office but a contracted position revocable by the monarch at his will (Le Goff 2004). Upon commission, intendants represent the sovereign in their locality, while local powerholders seek to retain as much autonomy over their own affairs as possible. Thus intendants were typically seen as outside intruders who would erode the authority of local strongmen (Collins 2009, 63).

The goal of the intendants is to facilitate two dimensions of public administration. First, given that a primary driver for this bureaucracy was the chronic inefficiency of revenue generation, the main job is to raise greater revenue by assisting and supervising the taxation effort for local officials (Gruder 1968, ch. 1). In early-modern times, European states typically farmed taxation to local financial officeholders, each of whom was responsible for collecting a certain amount as a quota. In France, officers such as the trésoriers and the élus traditionally assumed this responsibility but delayed it regularly. Even when they acted, they reassigned the tax burden disproportionately to politically powerless peasants in favor of their family members and other local powerholders (Gruder 1968, 4). The intendants were tasked to address this imbalance by ensuring that "the different aspects of taxation should not conflict and that the king obtained the fiscal resources he needed" (Bonney 1999, 130). Historians note that for the French state, intendants brought to the king greater taxes and the greater freedom of action, to the extent that they constitute "the linchpin of financial administration" (Bonney 1999, 129). Second, the intendants execute what present-day observers may term as "developmental" or "programmatic" policies. These include welfare, poor relief, food supply, and the building of roads and hospitals (Le Goff 2004). Today, these are public goods provided typically by (elected) officials in the executive branch of the government.

Recruitment is structured. Intendants are typically drawn from a pool of candidates in the midlevel position in the royal administration called the maîtres des requêtes (masters of requests). Although this office could lead to more senior and prestigious positions, it is venal such that wealthy families could take advantage of their status to jumpstart on the government career. ${ }^{5}$ Otherwise,

XIV and adopted the role of combined interior and finance minister. Colbert had once been an intendant of finance himself.

${ }^{5}$ The purchase of an office in the masters of requests must ultimately be approved by the king (Collins 2009, xlvi). 
prospective officials would need to spend several years in junior ranks such as conseillers in the Parlement or the Grand Council before being considered for promotion (Le Goff 2004). The maîtres are usually tasked to conduct paperwork and prepare other administrative duties for their ministerial superiors in their assigned councils. They observe and participate in the policymaking process and deliver reports as rapporteurs. Although they neither have a decision-making authority nor vote on a decision, they have chance to get to know senior officials and politicians personally and learn firsthand the policymaking process in the central government (Gruder 1968, 81-2). Previous research underscores that such experience seems to provide a foundation to be bureaucrats with specialized knowledge before they are granted the chance to become intendants (Gruder 1968, 83). The average age of becoming maittres des requêtes during the reign of Louis XV (1715-74) was twenty-nine, and most would-be intendants spent several years before the promotion (Le Goff 2004). The literature holds that there were typically 70-80 maitres during the early-modern period (Collins 2009, xlvi).

One of the key conditions for intendancy's success as a bureaucracy is whether it gives the staff an incentive to discharge the duty as expected. This is critical because many intendants serve in distant locals where their superiors are unable to monitor them. For the system to work, the French state must establish an institution that makes intendants stay loyal to the central government. Although few concrete mechanisms seem to be in place, the historical scholarship suggests two inducements. First, intendants are considered a highly prestigious position (Gruder 1968, 12), as the commissions are awarded competitively. The prestige may also stem from the fact that the intendant represents the sovereign in the assigned locality. Second, there is a degree of meritocracy. Intendants typically receive well-defined assignments, which in turn allows for objective evaluation based more on their performance than on the family status or other endogenous attributes. Since the appointment could lead to more senior positions in Paris, such as the State Councilors (Conseillers d'Etat), the intendants are expected to not just remain loyal to the state but to perform well.

One limitation of intendancy as a proto-bureaucracy is that it did not modernize the French state. The intendants helped strengthen it, but "the king did not use [them] to destroy the officers from 180,000 to 200,000 livres but fell by half in mid-century (Gruder 1968, 61-2). 
and establish 'absolute' government” (Collins 2009, 64). Venality remained. The maîtres des requêtes, a key mid-ranking office in the career of the royal administration, were open to purchase: wealthon average 150,000 livres-could buy an individual into the royal bureaucracy and an opportunity to be certainly involved in policymaking and possibly craft policy for the monarchy. ${ }^{6}$ This office is also a path to nobility. Personal ennoblement was granted in early-modern France if one's grandfather held a purchased office for twenty years. This privilege was extended to the maîtres des requêtes after 1644 (Bonney 1978, 76-7). In addition, Parisians had a disproportionate advantage over provincials in landing an entry-level position in the central government. The capital offered a much denser network of noble and prominent families and greater chances for young and ambitious men to catch attention from ministers and possibly get an offer, for instance, in judgeship at the court (Gruder 1968, 40-1). During the Louis XIV's reign, four years of experience in an important court seemed to be a prerequisite to be eligible to purchase the office of the maître des requêtes (Collins 2009, 192). Chances of entry into the royal administration were certainly unevenly distributed.

\section{Empirical Strategy}

The previous section indicates that historical research has produced extensive research on the role of intendants in centralizing the authority of early-modern France. Intendants illustrate historical works by serving as as the king's agents to enforce rules, assist in collecting taxes, and asserting authority in their assigned provinces. ${ }^{7}$ Quantitative evidence based on systematic research helps explain the extent to which the intendants contributed to the bureaucratization of the royal administration.

In the previous research on intendancy, John Armstrong (1972) is the only one that conducts a quantitative analysis. In his article, Armstrong compares the French intendancy to the Russian $g u$ bernators to assess either institution is advanced as an early-modern bureaucracy. Although the data

\footnotetext{
${ }^{6}$ The figure is drawn from Bonney $(1978,87)$. Also Gruder $(1968,61)$ provides a snapshot of increasing prices for this office: 180,000 livres in November 1674, 190,000 livres in February 1689, and 200,000 livres in June 1708.

${ }^{7}$ See, for instance, Beik (1985) for a generous use of intendants to support the main argument.
} 
set is publicly accessible, it has unfortunately been all corrupt and rendered machine-unreadable nearly thirty years after the publication. I had to construct a new one by first identifying two published sources that comprise the Armstrong data set, Paul Ardascheff (1909) and Vivian Gruder (1968). In addition, I take advantage of more recently published works and online databases to locate information not used in the Armstrong data set. These include, first, Sylvie Nicolas (1998), the publication that provides prosopographical descriptions of maitres des requêtes in the late eighteenth century and many of whom also served as intendants; second, François Alexandre Aubert de La Chesnaye-Desbois and Jacques Badier (1863-76), which constitutes a nineteen-volume set primarily on the biography of the French nobility ${ }^{8}$; third, Jean Baptiste Pierre Julien de Courcelles (1822-33), which offers genealogical information about the same group in a twelve-volume set; fourth, the online database of the Bibliothèque nationale de France $(\mathrm{BnF})$, which contains similar biographical and some career information about many intendants; and, finally, the geneanet, an online repository of genealogical data on a number of French nobility that goes as far back in time as the early sixteenth century. Published and online data on the prosopography of intendants rely primarily on either archival documents and historical sources such as Aubert de La ChesnayeDesbois and Badier (1863-76) and Courcelles (1822-33). Thus biographical information, including the dates of birth, death, and marriage, is mostly consistent across these sources.

My data set consists of 430 intendants who have at least one appointment when France ran the institution systematically from 1640 through 1789, the last year of the ancien régime. It counts all known individuals for the entire duration of the bureaucracy in all places of the appointments-both in continental France and its overseas territories such as Corsica, Guadeloupe (the French West Indies), the Mascarene Islands (Mauritius), New France (Québec), and Saint Domingue (Haiti). I have information about 430 intendants over the 150-year period, which yields a panel data set of 6,450 intendant-years by basing the decade as the time unit. This comes close to saturation in data collection. Armstrong $(1972,27)$ estimates that, based on his sample of 377 intendants for the period between 1661 and 1770, the universe of the intendants should be around 400. According

\footnotetext{
${ }^{8}$ The original editions were published by Aubert de La Chesnaye-Desbois alone between 1757 and 1761.
} 
to the article, his data set would have offered the name, the place of service, and the duration of service for each observation. Armstrong's data also seem to contain the date of death and the age of intendants who entered the French central government as maîtres des requêtes, but no information is documented.

In my data set, I have for each intendant-observation the complete data on the family name, mostly complete data on the given name, the date of birth for 372 individuals (or 86.5 percent of the entire observations), the place of birth which is often missing, the date of death for 397 individuals (92.3 percent), and the complete information on the place of appointment and the start and end date of appointment. Date of birth allows for precisely computing the age of appointment, while date of death helps understand when in the career stage these bureaucrats received the appointments. I have 369 officials (86 percent) on both the date of birth and the date of death. All intendants are male. This is a substantial improvement in the number of intendants whose date of birth is available: The information was available for 67 individuals (or 18 percent of the 377 intendants) in Armstrong $(1972,16)$. No data on the date of death has previously been documented.

I collect two additional types of data that have earlier been mostly lacked. The first relates to career. As discussed earlier, recruitment draws primarily from the lower-ranking office of the maittres des requêtes. Armstrong $(1972,13)$ provides data on the age of 54 individuals who had the maitreintendant path for two ends. One is to show that wealth can buy some young aspirants a way into the royal-administration career. Another is to provide quantitative evidence that this career ladder had some formal requirements for promotion. To address these points more fully, my data set offers information on 277 or nearly 65 percent of the observations who held the maitre office with the starting date and often the end date. The second type of data concerns family. These high-ranking bureaucrats not just come from an affluent background but are also well-connected with one another. The intendants in my data set include many whose kin members serve as colleagues. Of the 430 observations, 58 have their father holding the same position; similarly, 16 have a brother as a colleague. In total, 174 or 40 percent of the intendants have at least one kin relationship in one way or another, including, inter alia, the uncle, the granduncle, the grandson, the cousin, and the 
nephew. Little evidence is discussed on the presence of familial connections in Armstrong (1972).

Besides family, I compile marriage-related data. This type of information is significant, because many intendants are interlinked in this manner. It is another way through which these families make their ties deeper and stronger and this article is the first to document quantitative evidence. My data set identifies 375 (or over 87 percent of the intendants) known to get married at least once; of these, 322 or nearly three-quarters have the date of marriage and the name of wife. This is a new type of information on the study of the intendants.

Exploring kin and marriage data allows me to identify a third way of connection: endogamy or marriage within community. Two intendants from two separate families may be linked by forming an in-law relationship. It happens either when an intendant marries a female sibling or relative or when the wife of an intendant has her own sisters and/or other female relatives, such as aunts and female cousins, who marry another intendant. In my data set, 109 individuals have at least one endogamous tie with another; some have as many as seven such ties. Thus, these intendants knit a close community not just by bringing their own kin but also by practicing endogamy within a single bureaucracy. Like the marriage data, this is also a new type of information.

\section{Quantitative Evidence}

\section{Overall picture}

I first document evidence in two broad manners. The first is descriptive evidence from time-series and cross-sectional perspectives and the second provides a detailed discussion of how extensively familial and endogamous ties are constructed followed by a brief test of promotion within government.

The first dimension of descriptive evidence is the duration of appointment as exhibited in Figure 1. Of the 430 intendants who receive an appointment, approximately half (196 intendants or 45 percent) serve at least twice. Eight received five appointments and three of them get six appointments (the maximum recorded number), but since the number is so small that it is not shown in 
the figure.

Figure 1: Duration of appointment for 430 intendants for the first four appointments.

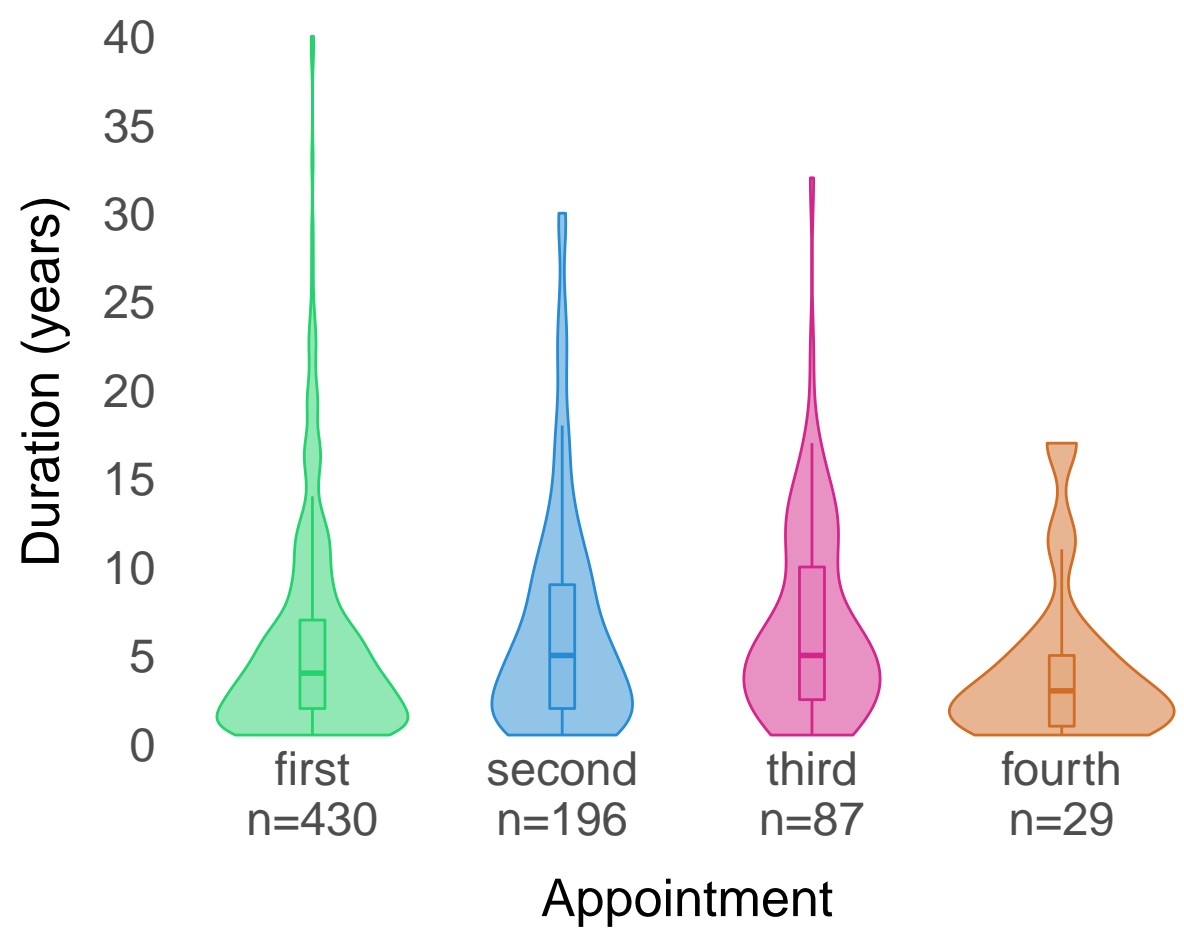

Notes: The boxplot is placed within each appointment, where the horizontal bar inside the box denotes the median value. A smoothed density around the boxplot indicates the variability of observation.

Source: See the Empirical Strategy section.

These posts last on average four to six years, suggesting that this is likely the standard duration upon commission. Figure 1 also indicates that the duration rule was not strictly enforced. In each appointment, some served for far longer than the average: in the first appointment, some stayed for thirty to forty years in a single place. Given that the average life expectancy of 369 intendants whose date of birth and date of death are both available is approximately 67 years, these intendants spent a majority of their life on a single commission. It is of use to remember that intendant appointments would be on a rotation system. The purpose was to prevent or minimize collusion between intendants and local officials due to the limited ability of senior officials in Paris to monitor the work of intendants on a regular basis. Figure 1 suggests that the French state was not particularly effective at implementing the rotation system. 
At the same time, there is evidence that intendancy was systematically practiced throughout the early-modern period. Here I explore two dimensions of variation. One is chronological. Figure 2 displays a time-series frequency, in a five-year moving average, for the entire period from 16401789. It indicates that once Cardinal Richelieu decided to rely on intendants for government, they were constantly dispatched throughout the domain. It is interesting to note that the French state never ceased to commission these posts during the Fronde (1648-53). The literature points out that the Fronde, which was a series of domestic revolts, occurred due in part to intendants who tried too aggressively to raise revenue so that intendancy had to stop or at least substantially declined during the Fronde (Collins 2009). Yet the data indicate that appointments continued to be made, despite that frequency declined in the early 1650s.

Figure 2: Frequency of intendancy appointments in a five-year moving average, 1640-1789.

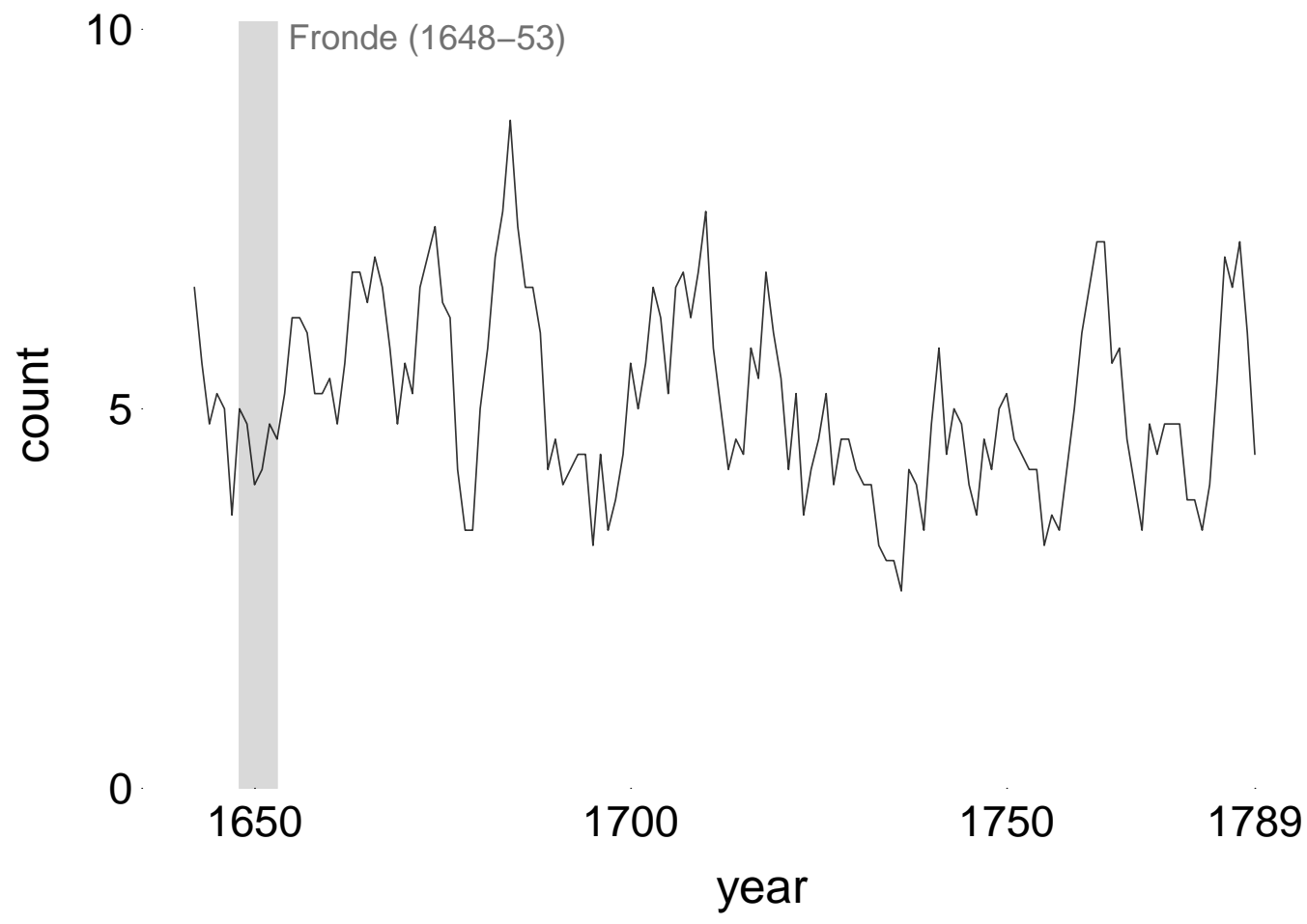

Source: See the Empirical Strategy section.

Another is geographical variation. To begin, I document the geographical distribution of appointments by counting the number of intendants in each généralité across the entire period. Since 
the généralité is no longer in use as an administrative unit, I redistribute the frequency to the level of the département (the county) for display. For visual simplicity, I use the median value of the distribution on the département level as the cutoff, in which the dark blue indicates above the median and the light blue indicates below the median. Figure 3 maps the geographical distribution. Consistent with the literature, it covers most of France, with a greater concentration on provinces close to the capital (i.e., pays d'élections), while non-French-speaking-minorities-heavy locales in Brittany in the northwest and in Occitan in the south (pays d'états) receive less attention.

\section{Figure 3: Ceographical distribution of intendancy appointments, 1640-17893.}

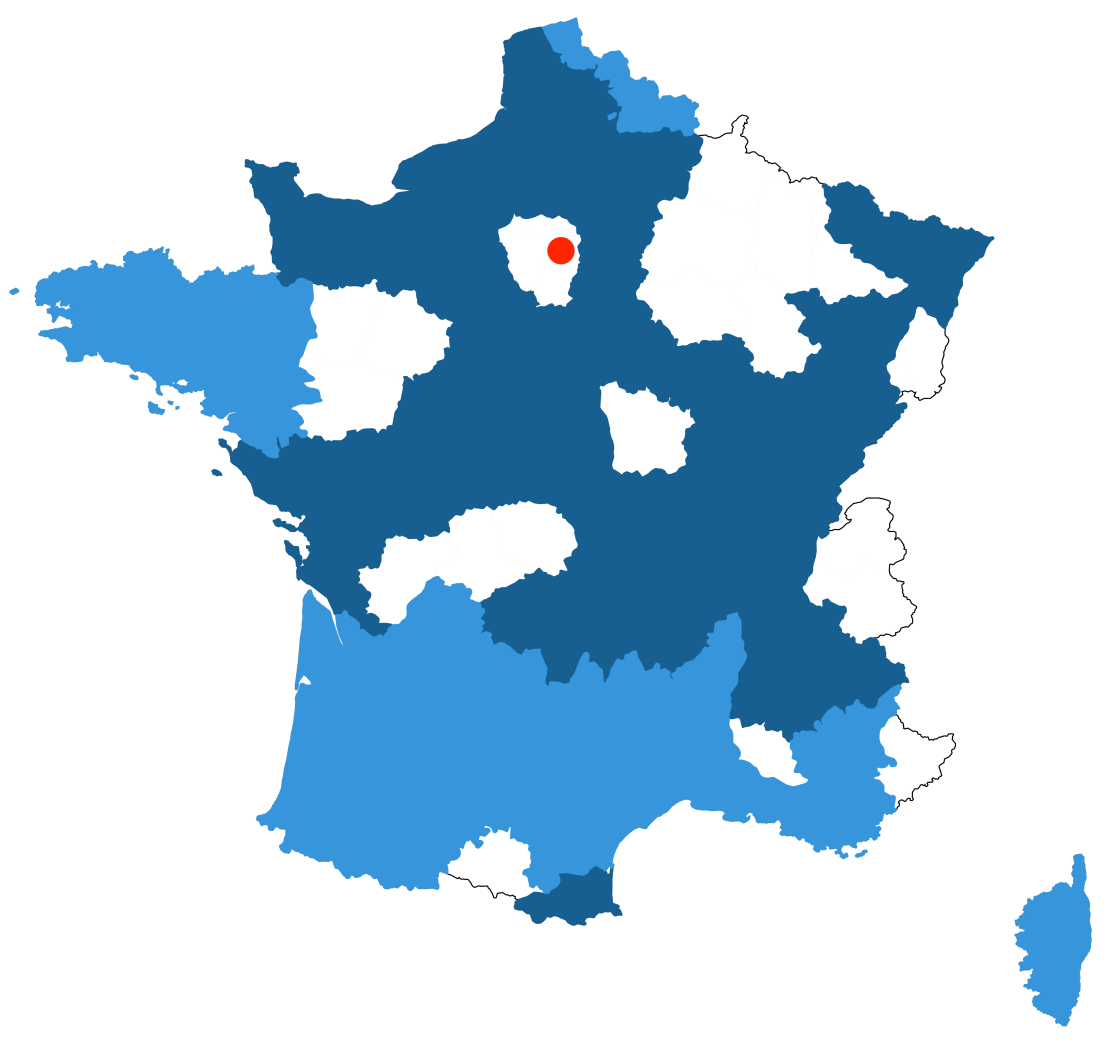

Notes: The red dot denotes Paris.

Source: See the Empirical Strategy section.

I explore the geographical dimension further by including appointments in the French overseas territories. As with continental France, the monarch also relied upon intendants to govern his 
overseas domains, including Corsica, Québec (Nouvelle France), Guadeloupe or the French West Indies (Martinique), Haiti (Saint-Domingue), and Mauritius or the Mascarene Islands (archipel des Mascareignes). Although they are far-flung places from Paris, they continuously received intendants during the early-modern period as shown in Figure 4. It conveys four dimensions of information: the number of intendants on the vertical axis, the geographical distance from Paris on the horizontal axis, whether locality is within continental France or in overseas territory in two different colors, and the proportion of intendants among all places in the size of the bubble. The figure suggests the extent to which the institution of bureaucracy was used for governance. That the French state depended on intendancy in islands $6,000-8,000 \mathrm{~km}$ away from the capital indicates the centrality of the institution to public administration for early-modern France.

Figure 4: Frequency of intendancy appointments in relation to the distance to Paris, 1640-17893.

40

continental France

overseas territory
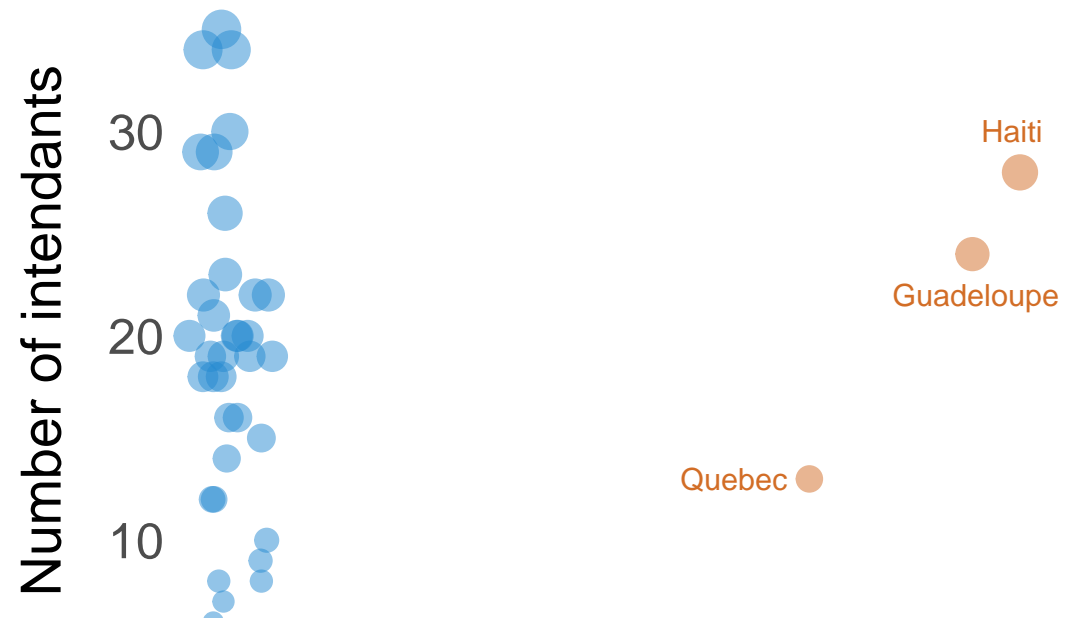

Quebec

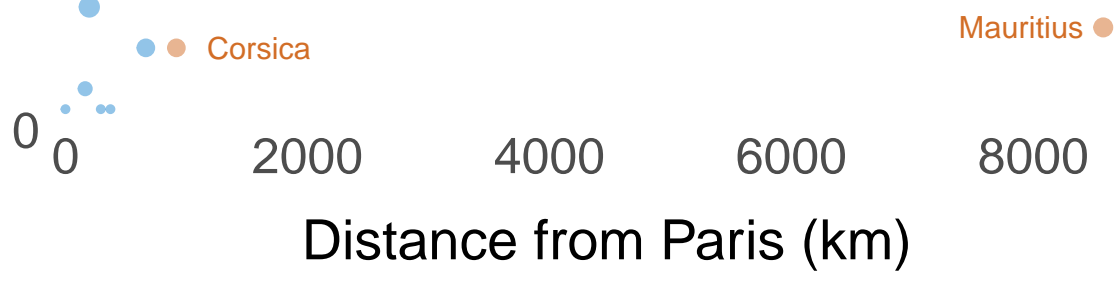

Source: See the Empirical Strategy section.

In addition to the variation in the scope and geography of appointments, the dataset offers detailed information about the intendants' career. The analysis is now confined to those at least with 
the date of birth. I document the distribution of age for 372 of the 430 intendants with the date of birth, as shown in Figure 5. The mean age of the first appointment is 38 years old and the median age is 36 . The mean and median ages for all the subsequent appointments increase by four to five years (i.e., the standard duration of each commission). Given that the intendant enjoyed a high degree of authority as the representative of the sovereign, the median age of 36 to 40 in the first two appointments appears young. At the same time, Figure 5 indicates that the age distribution is wide across the appointments. Some land this position in the early to mid-20s-the youngest age in my data set is 21 - while others receive an appointment in the 70 s or even older. It is also worth noting that there is a long tail on the distribution. Since intendancy is not a particularly senior position in the royal administration, appointments given to "elderly" bureaucrats strike as puzzling. Wide distributions suggest that the structure of promotion was not well-established by modern standard.

\section{Figure 5: Distribution of intendant age for the first four appointments.}

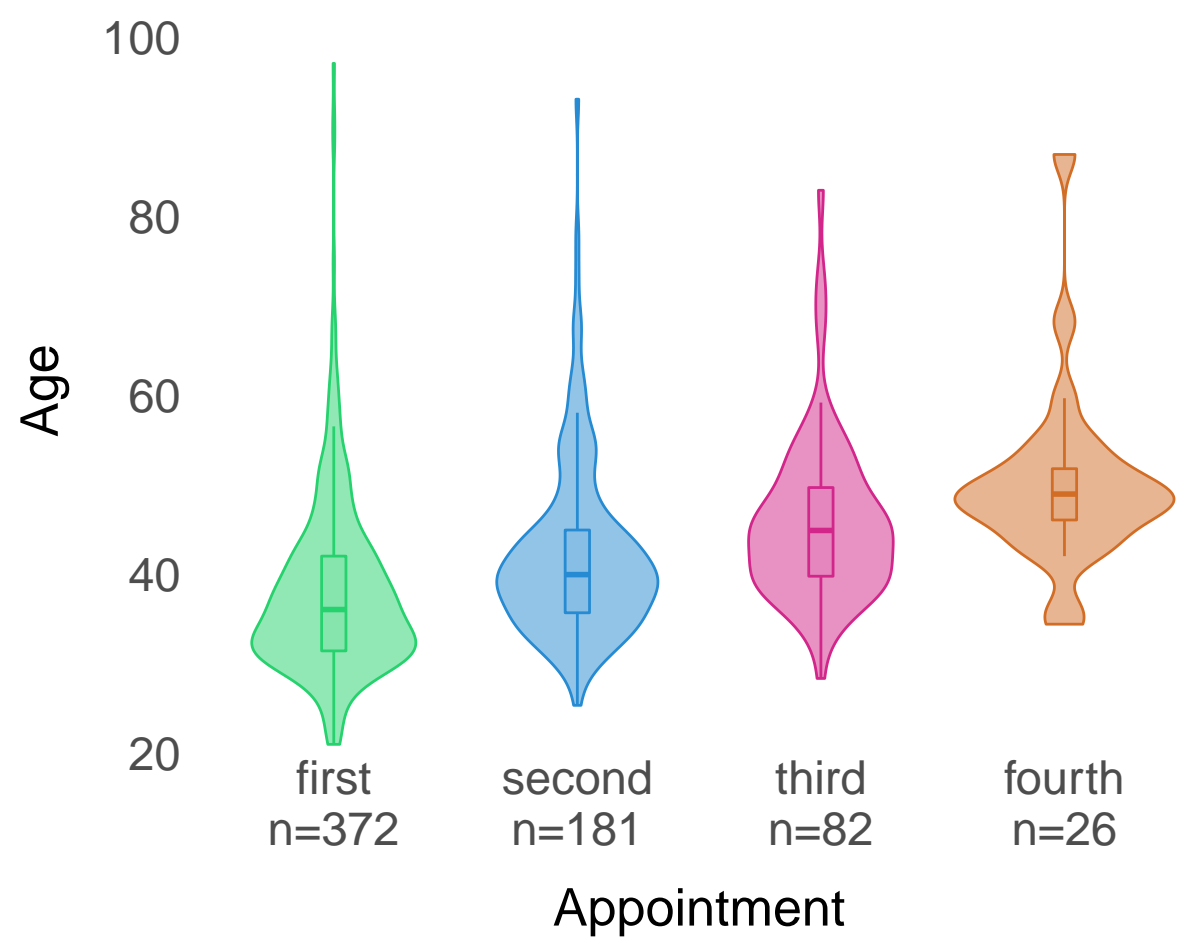

Notes: The boxplot is placed within each appointment, where the horizontal bar inside the box denotes the median value. A smoothed density around the boxplot indicates the variability of observation.

Source: See the Empirical Strategy section. 


\section{Detailed evidence}

I provide further quantitative evidence on two specific issues. One is family. As discussed above, recruitment may be based on less merit than nepotism. Here "nepotism" means that one's social background in terms of family and place of origin, which is exogenously determined at birth, may favor some over others upon commission. Another is promotion within the royal administration, particularly the bridge between the maîtres des requêtes and intendancy. Previous research maintains that the former is practically a prerequisite to the latter (Collins 2009, 64). My data set does not permit a regression analysis that tests the extent to which experience in the maitre office weighs more than others for the promotion by controlling for relevant factors. I instead document descriptive evidence that provides a broader link between the two positions.

The first test is family. In the early-modern French state, certain prominent families seemed to populate the mid-level and senior ranks, including the maîtres des requêtes and intendancy. As Bonney (1978, ch. 4) points out, some families work for the government across generations and make service a family tradition. This practice seems contradictory to the Weberian principle of impersonality of recruitment and assignment in modern bureaucracy. I provide two types of evidence on family and marriage. The first is kin as colleagues. My data set shows the extent to which intendants have their kin as colleagues, including not just immediate family members such as one's brothers, father, grandfather, and children, but also one's relatives such as cousins and uncles. The second is connections through marriage. Even when a family does not have a son, families can become prominent by marriage. For instance, a father who only has daughters can arrange a marriage with prominent families with sons so that the daughters' family can enter the network of noble or influential families. In this way, those who see government service as a vocation or a stable source of income can find viable heirs and ensure the family business continues from one generation to the next. Given that such marriage patterns occur frequently within small communities of families, I call it "endogamy." Endogamous relations can take many forms: for familiar ones, an intendant can be a son-in-law or a brother-in-law; for less familiar ones, he can be an uncle-in-law, a nephewin-law, a first-cousin-in-law, or even a stepson-in-law through a parent's re-marriage. These labels 
unfamiliar to modern readers denote how expansive endogamous relations can become. No quantitative evidence has been offered on these subjects; in particular, the issue of endogamy has yet to be explored in the literature.

A few summary statistics illustrate the depth of kin and endogamous colleagues among the intendants. First, Table 1 exhibits the number of intendants about whether their kin serve as colleagues or whether they have endogamous ties with at least another intendant. It is sorted by the decreasing number of intendants on the city level which is the unit of analysis, given that multiple intendants are allowed to serve in a single province. It is possible that one has a colleague in both categories, so the sum of the two types can exceed the total number of intendants for each city. 
Table 1: The number of kin and endogamous colleagues on the city level, 1640-1789.

\begin{tabular}{|c|c|c|c|c|}
\hline City & Province & Intendants & Kin & Endogamy \\
\hline Moulins & Bourbonnais & 35 & 13 & 12 \\
\hline Limoges & Limousin & 34 & 16 & 11 \\
\hline Rouen & Normandy & 34 & 15 & 17 \\
\hline Riom & Auvergne & 30 & 13 & 13 \\
\hline Soissons & Île-de-France & 29 & 12 & 12 \\
\hline Tours & Touraine & 29 & 10 & 14 \\
\hline Poitiers & Poitou & 26 & 13 & 7 \\
\hline Chalons-sur-Saône & Burgundy & 23 & 0 & 0 \\
\hline Amiens & Picardy & 22 & 15 & 8 \\
\hline Montauban & Guyenne-Gascony & 22 & 7 & 9 \\
\hline Pau & Béarn & 22 & 11 & 10 \\
\hline Caen & Normandy & 21 & 10 & 2 \\
\hline Grenoble & Dauphine & 20 & 9 & 7 \\
\hline La Rochelle & Aunis & 20 & 6 & 3 \\
\hline Lyon & Lyonnais & 20 & 9 & 10 \\
\hline Paris & Île-de-France & 20 & 14 & 12 \\
\hline Alençon & Normandy & 19 & 11 & 9 \\
\hline Bordeaux & Guyenne-Gascony & 19 & 7 & 8 \\
\hline Metz & Trois-Évêchés & 19 & 11 & 8 \\
\hline Perpignan & Roussillon & 19 & 7 & 1 \\
\hline Bourges & Berry & 18 & 5 & 5 \\
\hline Dijon & Burgundy & 18 & 11 & 4 \\
\hline Orléans & Orléanais & 18 & 11 & 5 \\
\hline Besançon & Franche-Comté & 16 & 7 & 5 \\
\hline Strasbourg & Alsace & 16 & 9 & 6 \\
\hline Auch & Guyenne-Gascony & 15 & 7 & 5 \\
\hline Rennes & Brittany & 14 & 8 & 6 \\
\hline Lille & Flanders-Hainaut & 12 & 6 & 5 \\
\hline Valenciennes & Flanders-Hainaut & 12 & 4 & 3 \\
\hline Aix & Provence & 10 & 6 & 3 \\
\hline Toulouse & Languedoc & 9 & 7 & 3 \\
\hline Dunkirk & Dunkirk & 8 & 2 & 1 \\
\hline Montpellier & Languedoc & 8 & 6 & 0 \\
\hline Nancy & Lorraine & 7 & 6 & 0 \\
\hline Maubeuge & Flanders-Hainaut & 6 & 0 & 2 \\
\hline Bayonne & Guyenne-Gascony & 4 & 1 & 2 \\
\hline Artois & Picardy & 2 & 2 & 1 \\
\hline Trévoux & Lyonnais & 1 & 0 & 0 \\
\hline Ypres & Flanders-Hainaut & 1 & 1 & 1 \\
\hline
\end{tabular}

Notes: Sorted by the descending number of intendants on the city level. 
Source: See the Empirical Strategy section.

Table 1 indicates that kin or endogamous ties are observed in every city. The term "colleague" does not mean that kinsmen serve at the same time; it simply represents an individual who has kin or endogamous colleagues is posted for the same city before or after his appointment. Interestingly, no such ties are found for France's overseas territories (hence not reported). At the time, it may be natural to think that having such "nepotistic" ties abound. The degree of these connections suggests that they could rather send a positive signal to win a commission. Extant literature notes that at the same time, objective qualifications for government officials were hard to find due to the lack of verification methods. By the sixteenth century, for instance, one could claim to belong to a "nobility" just by offering an oral proof (Bonney 1978, 76). For a similar reason, genealogy based on social titles and ranks, such as sieur, seigneur, or chevalier, remained unverifiable thus unreliable (Gruder 1968, ch. 5). In the absence of centralized examinations as adopted in pre-modern China and Korea, the government might as well resort to an unsystematic yet more reliable method-by assessing the performance of currently-serving intendants by senior ministers such as Richelieu and Colbert. Intendants with a passing "grade" can signal that their kinsmen and in-laws may be as skilled as they can.

\section{Figure 6: Family tree of the Lefèvre d'Ormessons in the seventeenth and eighteenth centuries.}

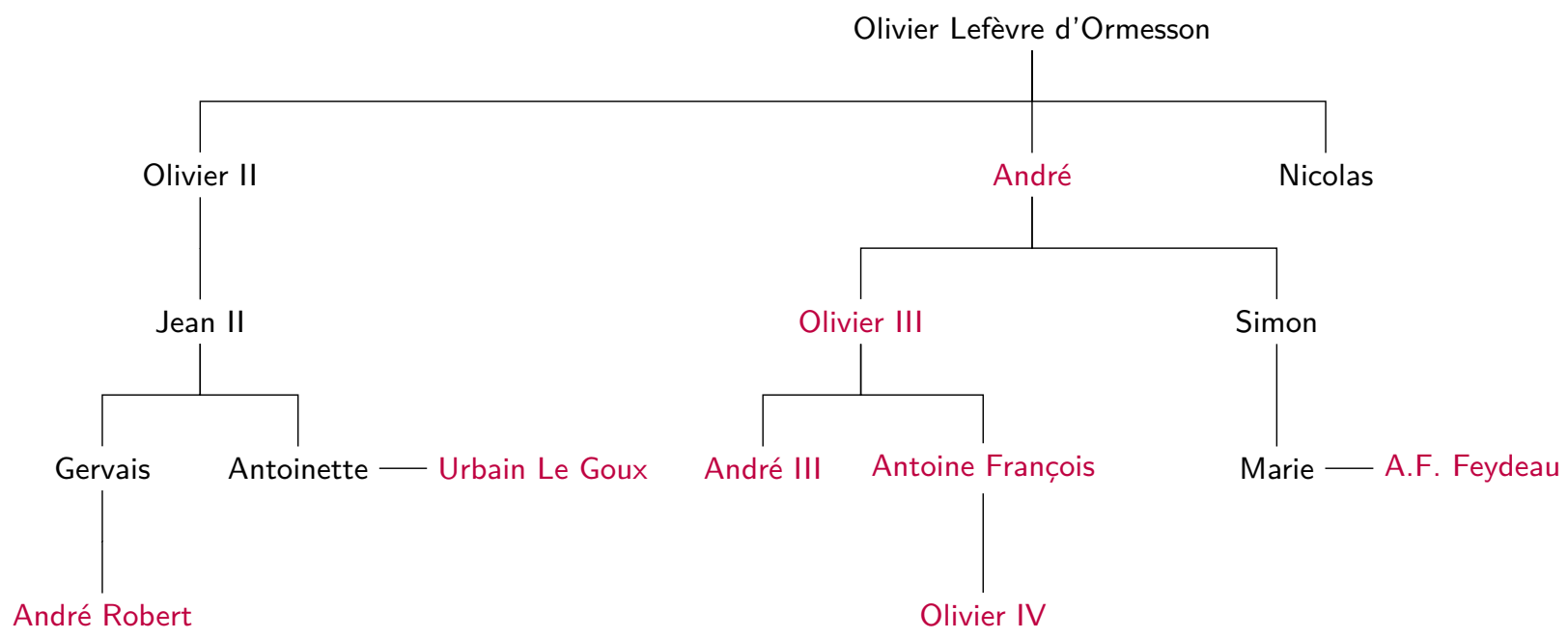


Notes: Colored names indicate intendants. André Lefèvre d'Ormesson is an intendant but serves before 1640, the start year of my data set, so he is not counted.

Source: See the Empirical Strategy section.

For a concrete illustration of the extent of kinship and endogamy in intendancy, I describe the case of the Lefèvre d'Ormesson family whose relationships are depicted in Figure 6. The colored name indicates those who served as intendants. This is an adequate example as it contains both the cross-generational dimension of intendancy within a single family and the cross-sectional expansion of family networks via endogamy. It represents a total of eight intendants from three families across four generations. The family is one of those conferred upon the nobility status by possessing the venal office of the secrétaire du roi (Bonney 1978, 76-8). It seems that André (1577-1665) was the first in the family to open the career path of the royal administration. After becoming a maitre des requêtes in 1605, André went on to become a state councilor (Conseiller d'État) by replacing the deceased father, Olivier I, and to complete a short, two-time tour in Champagne as an intendant from the 1610s to the 1620s (Bonney 1978, 106). ${ }^{9}$ By his death, he came to occupy an influential position in policymaking by serving as a doyen (the most senior person) in the king's council.

As Figure 6 shows, the Ormesson family alone bears six intendants from among the direct descendants of Olivier I (1525-1600, at the top): besides André, Olivier III (1616-86), who is a son of André, two of Olivier III's sons André III (1644-84) and Antoine François (1651-1712), Olivier IV (1686-1744) who is a son of Antoine François, and André Robert (1681-1735) who is a great-great grandson of Olivier I. In addition, two intendants join the family via marriage: Urbain Le Goux (1643-1721) and Anne François Feydeau (1645-92), each of whom married a female member of the Ormessons. Through marriage, Le Goux becomes an uncle-in-law of André Robert and so does Olivier III for Feydeau. While Le Goux seems to be alone in his own family serving as an intendant, Feydeau is from another prominent family who produce as many, if not more, intendants as the Ormessons: to give a few names, first cousin Denis Feydeau II, his son Paul Esprit, and two

\footnotetext{
${ }^{9}$ André had completed his intendancy appointments before the year 1640, the start year of my data set, so his information is not recorded.
} 
brothers of Denis II's mother (Jean Rouillé III and Pierre Claude Rouillé). ${ }^{10}$ There are a total of nine intendants besides Anne François Feydeau himself within two generations in his own family.

The Ormessons have varying destinations in their intendant appointments. Excluding André, most of the seven intendants served in the late seventeenth century for a total of fourteen appointments in ten cities. These appointments are concentrated in the Île-de-France region or Rouen, a major Normandy town close to Paris. This summary data suggests that members from a single family do not necessarily go to the same place and pass the commission from one generation to the next. At the same time, it is plausible that bearing a well-known surname or marrying into one could give these individuals an advantage over winning an appointment in preference of those from less prominent family backgrounds. Such an analysis is beyond the scope of this paper, but the case of the Ormessons illustrates extensive networks that aspiring families build and expand.

A second test is on the promotion to an intendant after holding the maitre office. There is a strong link between the two positions in the historical literature. The event that made the connection virtually inseparable in the royal-administration career is the ruling on October 27, 1674, which stipulates that the maitre office essentially be a prerequisite for the eligibility of intendancy (Bonney 1978, 110). My data set can assess the impact of this ruling. A straightforward test is to divide the intendant appointments with the year 1675 as the cutoff and to examine whether individuals held the position of a maitre in each category. Table 2 summarizes the evidence.

\section{Table 2: Data on the impact of the October 1674 ruling that the maîtres des requêtes (MOR) are a prerequisite for intendancy.}

\begin{tabular}{lrrrrr}
\hline & Intendants (1) & MOR (2) & $(2) /(1)(\%)$ & No MOR & No MOR data \\
\hline Before 1675 & 129 & 83 & 64.3 & 4 & 42 \\
After 1675 & 301 & 194 & 64.5 & 7 & 100 \\
\hline
\end{tabular}

Source: See the Empirical Strategy section.

Of the 129 intendants appointed before 1675, 83 (or 64.3 percent) have the recorded date of

\footnotetext{
${ }^{10}$ In addition, Anne François Feydeau's father, Charles, has a sister who married an intendant, Antoine Le Camus (1603-87), and another sister whose daughter married an intendant, Charles Le Jay de Tilly (1613-71).
} 
serving as maîtres des requêtes. In my data set, 42 have no clear information about whether they held the office prior to their intendant appointment. Of the 301 intendants who served in or after 1675, 194 (or 64.5 percent) held the maître office and 100 individuals have no data on it. Table 2 suggests that, of those who have the record, there is virtually no difference in the proportion of the maîtres des requêtes experience between the two periods. One implication of this evidence is that the 1674 ruling was less a policy shift designed to provide bureaucratic training than an affirmation of the standard practice already in place. At the same time, missing data merits attention. In each period, more than 30 percent of the data on whether the experience of the maitre office is missing. Specialized publications do not always report this information, even though they never fail to make the link between the two positions. ${ }^{11}$ As with data on the intendants, those on the maitres des requêtes have yet been centralized. Further research will clarify the impact of the 1674 ruling on the institutionalization of bureaucratic training.

My data offers stronger evidence on a broader trend. Of the 277 individuals who held the maitre position and became intendants between 1640 and 1789, date of birth is known for 219 individuals (or 79 percent of the 430 intendants). Panel A of Figure 7 compares the age of acquiring the maitre office with the age of the first intendant appointment. The mean and median age of the former is, respectively, 30 and 28 years old, eight years younger than the latter in each statistic. Panel A corroborates extant research in that the maitre office is a mid-level position for young aspirants from wealthy families to start a career and gain experience in the government. Panel B shows the time lag between the maitre and intendancy. The average is 7.3 years, and this is the time in which those maitres with the career ambition would need to compete with others and perform well to be noticed by senior ministers and win the eligibility for a potential intendant. At the same time, Figure 7 indicates that some individuals had the opposite career path as shown in gray, i.e., becoming intendants before serving as maîtres. Although it provides evidence that the career structure in promotion is not entirely rigid, it indicates that a majority do follow a trend and create a de facto career path for those in entry-level positions.

\footnotetext{
${ }^{11}$ Nicolas (1998) seems an exception, although it focuses on two decades prior to the end of the ancien régime.
} 
Figure 7: Comparison between masters of requests and first intendancy appointment.

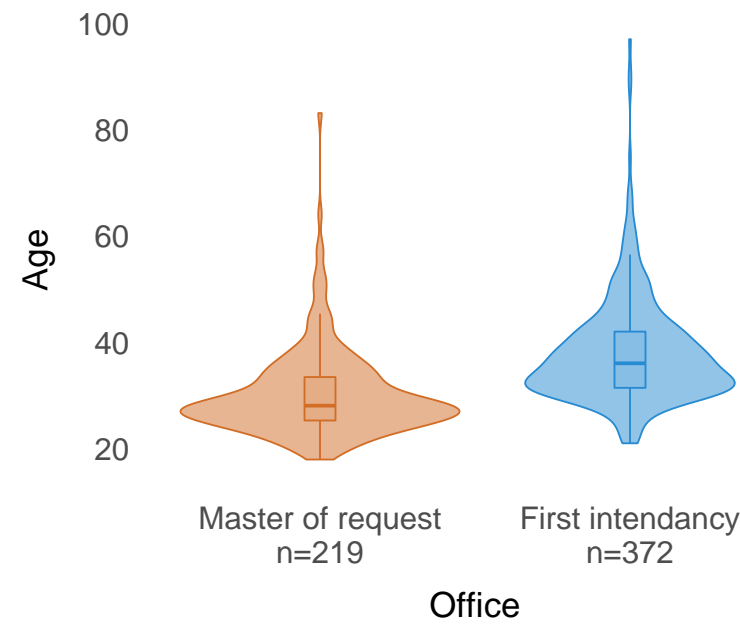

(a) Age comparison

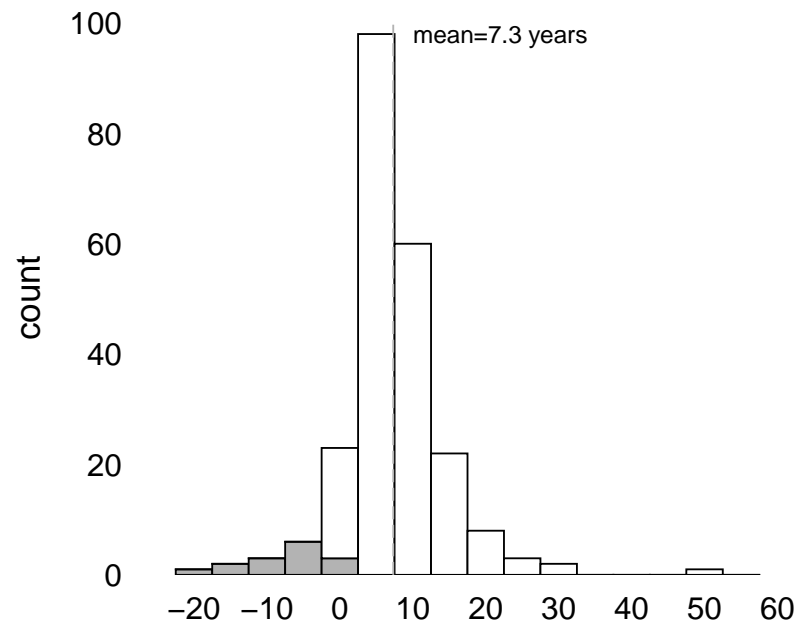

(b) Time difference between two appointments

Source: See the Empirical Strategy section.

Evidence from the new data set on 430 intendants from 1640-1789 yields three broad points. First, the appointment data reveals that there is a great variability in the age of commission and service duration. This suggests that the government did not devise a set of policies or a guideline about minimum qualifications that intendant candidates ought to have and that it did not seriously consider introducing any cap on the age or duration for the intendants. The fact that rotating appointments were not strictly enforced indicates that senior ministers in Paris overlooked the possibility of collusion between intendants in the field and provincial officials-or gave up monitoring it from the capital. Second, my evidence provides support for the convention that the French government relied on intendancy to strengthen its authority and facilitate provincial governance, even during major crises like the Fronde. It also supports the prevailing view that the intendants were dispatched to much of France with more serving in the core domain of the pays d'élections than in the recently acquired territories of the pays d'états. In addition, my data set highlights that the system was extended beyond continental France to govern the country's overseas territories. This might be the attempt of the ancien régime to achieve uniformity in governance across its all domains. Finally, I provide new data on kin and endogamous relations among the intendants. The 
degree of connections, made both across generations and across families, suggests that the principle of impersonality in recruitment was unlikely to be in place at the time. Endogamy practically constitutes a "proof" that family name or family connections likely mattered a great deal in terms of intendant appointment and promotion for these government officials.

\section{Conclusion}

This paper explores the French institution of intendancy, one of the first to possess attributes of modern bureaucracy in Europe (Kettering 1986). Historians of French political development stress the role of the intendants in the centralization and consolidation of the royal government's authority, although few quantitative works have been published. I fill the gap by providing a new data set, which covers the near universe of 430 intendants from 1640 through 1789 and their every assignment. My main contribution is to offer quantitative evidence that describes broad trends of the bureaucracy in terms of appointment age, service duration, place of appointment, and frequency of appointment over time. My data also reveals the extent to which intendancy allows for those with kin and endogamous ties as colleagues. The quantitative evidence documented herein not only provides support for intendancy as an incipient bureaucracy but also presents limitations in terms of operation and recruitment.

My paper draws implications for political and economic development in developing countries. As recent studies indicate, one of the thorny challenges of sustainable economic development is the absence of an effective, functioning bureaucracy (Fukuyama 2011). Although developing states adopt the same policies and rules as wealthier states, they are simply unable to execute them because they do not have the capacity to organize and run the system as effectively as advanced economies (Andrews, Pritchett, and Woolcock 2017). This literature suggests that devising institutions from the bottom-up to structure an incentive to follow the rules, rather than implanting ones from elsewhere, is a more effective approach to addressing these challenges. My paper provides evidence from bureaucracy-building in early-modern France on the complexity of establishing a new bu- 
WIAS Discussion Paper No.2020-002

reaucracy out of the existing state organizations. 


\section{References}

Allen, E. John B. 1972. Post and Courier Service in the Diplomacy of Early Modern Europe. The Hague: Marinus Nijhoff.

Andrews, Matt, Lant Pritchett, and Michael Woolcock. 2017. Building State Capability: Evidence, Analysis, Action. New York: Oxford University Press.

Ardascheff, Paul. 1909. Les intendants de province sous Louis XVI. Paris: Félix Alcan.

Armstrong, John A. 1972. “Old-Regime Governors: Bureaucratic and Patrimonial Attributes.” Comparative Studies in Society and History 14(1): 2-29.

Aubert de La Chesnaye-Desbois, François Alexandre, and Jacques Badier, eds. 1863-76. Dictionnaire de la Noblesse: Contenant les généalogies, l'histoire et la chronologie des families nobles de la France, l'explication de leurs Armes et l'état des grandes terres du royaume. Vol. 1-19. 3rd ed. Paris: Schlesinger Frères.

Beik, William. 1985. Absolutism and Society in Seventeenth-century France: State Power and Provincial Aristocracy in Languedoc. Cambridge: Cambridge University Press.

Beramendi, Pablo, Mark Dincecco, and Melissa Rogers. 2019. "Intra-Elite Competition and LongRun Fiscal Development." Journal of Politics 81(1): 49-65.

Besley, Timothy, and Torsten Persson. 2009. “The Origins of State Capacity: Property Rights, Taxation, and Politics." American Economic Review 99(4): 1218-44.

Besley, Timothy, and Torsten Persson. 2010. "State Capacity, Conflict, and Development." Econometrica 78(1): 1-34.

Bonney, Richard J. 1978. Political Change in France under Richelieu and Mazarin 1624-1661. London: Oxford University Press.

Bonney, Richard J. 1981. The King's Debts: Finance and Politics in France, 16589-1661. New York: Clarendon Press.

Bonney, Richard J. 1999. "France, 1494-1815”. In The Rise of the Fiscal State in Europe, c.1200-1815, ed. Richard Bonney. New York: Oxford University Press, pp. 123-76.

Collins, James B. 1988. Fiscal Limits of Absolutism: Direct Taxation in Early Seventeenth-Century France. Berkeley and Los Angeles: University of California Press.

Collins, James B. 2009. The State in Early Modern France. 2nd ed. New York: Cambridge University Press.

Courcelles, Jean Baptiste Pierre Julien de, ed. 1822-33. Histoire généalogique et héraldique des pairs de France: des grands dignitaires de la couronne, des principales familles nobles du royaume et des maisons princières de l'Europe, précédée de la généalogie de la maison de France. Vol. 1-12. Paris: L'auteur. 
Dincecco, Mark. 2009. "Fiscal Centralization, Limited Government, and Public Revenues in Europe, 1650-1913." Journal of Economic History 69(1): 48-103.

Dincecco, Mark. 2015. “The Rise of Effective States in Europe." Journal of Economic History 75(3): 901-18.

Downing, Brian M. 1992. The Military Revolution and Political Change: Origins of Democracy and Autocracy in Early Modern Europe. Princeton: Princeton University Press.

Elliott, J.H. 1992. “A Europe of Composite Monarchies.” Past and Present 137: 48-71.

Ertman, Thomas. 1997. Birth of the Leviathan: Building States and Regimes in Medieval and Early Modern Europe. New York: Cambridge University Press.

Fukuyama, Francis. 2011. The Origins of Political Order: From Prehuman Times to the French Revolution. New York: Farrar, Straus and Giroux.

Garfias, Francisco. 2018. "Elite Competition and State Capacity Development: Theory and Evidence from Post-revolutionary Mexico." American Political Science Review 112(2): 339-57.

Gorski, Philip S. 2003. The Disciplinary Revolution: Calvinism and the Rise of the State in Early Modern Europe. Chicago: University of Chicago Press.

Gruder, Vivian R. 1968. The Royal Provincial Intendants: A Governing Elite in Eighteenth-Century France. Ithaca: Cornell University Press.

Hoffman, Philip T. 2015. Why Did Europe Conquer the World? Princeton: Princeton University Press.

Johnson, Noel D., and Mark Koyama. 2014. "Tax Farming and the Origins of State Capacity in England and France." Explorations in Economic History 51(1): 1-20.

Johnson, Noel D., and Mark Koyama. 2017. "States and Economic Growth: Capacity and Constraints." Explorations in Economic History 64: 1-20.

Kettering, Sharon. 1986. Patrons, Brokers, and Clients in Seventeenth-Century France. New York: Oxford University Press.

Kiser, Edgar. 1994. "Markets and Hierarchies in Early Modern Tax Systems: A Principal-Agent Analysis." Politics and Society 22(3): 284-315.

Koenigsberger, H.G. 1987. Early Modern Europe, 1500-1789. London: Longman.

Le Goff, T.J.A. 2004. "Intendants”. In Europe, 1450 to 1789: Encyclopedia of the Early Modern World, ed. Jonathan Dewald. Vol. 3. New York: Charles Scribner's Sons, pp. 277-80.

Levi, Margaret. 1988. Of Rule and Revenue. Berkeley and Los Angeles: University of California Press.

Mares, Isabela, and Didac Queralt. 2015. “The Non-democratic Origin of Income Taxation.” Comparative Political Studies 48(14): 1974-2009. 
Migdal, Joel S. 1988. Strong Societies and Weak States: State-Society Relations and State Capabilities in the Third World. Princeton: Princeton University Press.

Nexon, Daniel H. 2009. The Struggle for Power in Early Modern Europe: Religious Conflict, Dynastic Empires, and International Change. Princeton: Princeton University Press.

Nicolas, Sylvie. 1998. Les Derniers Maîtres des Requêtes de l’Ancien Régime (1771-1789): Dictionnaire Prosopographique. Paris: École des Chartes.

Olson, Mancur. 1993. “Dictatorship, Democracy, and Development." American Political Science Review 87(3): 567-76.

Putnam, Robert D. 1993. Making Democracy Work: Civic Traditions in Modern Italy. Princeton: Princeton University Press.

Sasaki, Yu. 2020. “Ethnic Autonomy." Mimeo.

Scott, James C. 1998. Seeing Like a State: How Certain Schemes to Improve the Human Condition Have Failed. New Haven: Yale University Press.

Spruyt, Hendrik. 1994. The Sovereign State and Its Competitors: An Analysis of Systems Change. Princeton: Princeton University Press.

Strayer, Joseph R. 1970. On the Medieval Origins of the Modern State. Princeton: Princeton University Press.

Tilly, Charles. 1992. Coercion, Capital, and European States, AD 990-1992. Malden, MA: Blackwell.

Vittu, Jean-Pierre. 2001. "Instruments of Political Information in France". In The Politics of Information in Early Modern Europe, ed. Brendan Dooley and Sabrina A. Baron. London and New York: Routledge, pp. 160-78.

Vogler, Jan P. 2018. “The Political Economy of Public Bureaucracy: The Emergence of Modern Administrative Organizations.” Mimeo.

Wang, Yuhua. 2019. "Elite Kinship Network and State Strengthening: Theory and Evidence from Imperial China." Mimeo.

Weber, Max. 1978. Economy and Society: An Outline of Interpretive Sociology. Edited by Guenther Roth and Claus Wittich. Berkeley: University of California Press.

Ziblatt, Daniel. 2006. Structuring the State: The Formation of Italy and Germany and the Puzzle of Federalism. Princeton: Princeton University Press. 